\title{
Compositional Changes of PBL Population in Patients With Chronic Hepatitis B Virus Infection
}

\author{
Alireza Khabiri, Mohsen Abolhassani, \\ Sudabeh Aslani, Hiedeh Darabi, Farideh Bagheri \\ and Mohammad-Hossein Alimohammadian
}

Department of Immunology, Pasteur Institute of Iran, Tehran 13164, Iran

In this report we have analysed the peripheral blood lymphocyte of several patients with chronic hepatitis $B$ virus infection with flow cytometry. Based on the presence and absence of the $\mathrm{HBeAb}$, patients were divided into two groups. In both, all the patients were HBsAg positive with normal range of serum alanine aminotranferase $(23.9 \pm 17.8)$. We have found that the immunophenotypic profiles of patients were different from healthy donors with significant decrease in $\mathrm{CD}_{3}^{+} \mathrm{T}$ cells, specially $\mathrm{CD}_{8}{ }^{+} \mathrm{T}$ cells and a siginificant increase in the $\mathrm{CD}_{19}{ }^{+} \mathrm{B}$ cells. The differences were seen in other subset of $\mathrm{T}$ cells $\left(\mathrm{CD}_{4}^{+}\right)$or NK cells $\left(\mathrm{CD}_{56}{ }^{+} / \mathrm{CD}_{16}{ }^{+}\right)$and HLA-DR markers were not significant. When the phenotypic profiles of both groups were compared with each other, such changes were more dominant in group II, with $\mathrm{HBeAb}$ positive than in group I, with $\mathrm{HBeAb}$ negative. Also, we have seen a correlation between the increase of $\mathrm{CD}_{19}{ }^{+} \mathrm{B}$ cells and the decrease of $\mathrm{CD}_{3}{ }^{+} \mathrm{T}$ cells. No such correlation was observed with other cells.

Kev Words: Hepatitis B virus, chronic HBV infection, HBsAg, HBeAg, HBeAb, lymphocyte subset, flow cytometry.

Hepatitis B is one of the major diseases of mankind and is now preventable with safe and effective vaccines. Out of the 1 billion people who have been infected with the virus, more than 350 million are chronic carriers of the virus. The hepatitis B virus (HBV) is a noncytopathic, enveloped virus that causes acute and chronic liver disease and hepatocellular carcinoma [1]. These chronic carriers are at high risk of death from cirrhosis of the liver and liver cancer, diseases that kill about 1 million people each year. Primary HBV infection with an infected host may be asymptomatic or results in varying degrees of acute liver injury [1]. Approximatelly $5 \%$ to $10 \%$ of infected adults will not resolve the primary infection and go to a persistent infection with different characteristics.

Received on 27 June 2001; revised 6 December 2001.

Address for correspondence: Dr. Mohsen Abolhassani. Department of Immunology, Pasteur Institute of Iran, Tehran 13164, Iran. Phone/Fax: (98-21) 649-2596

E-mail: abolhassani@institute.pasteur.ac.ir

The Brazilian Journal of Infectious Diseases 2001;5(6):345-351. (C) 2001 by The Brazilian Journal of Infectious Diseases and Contexto Publishing. All rights reserved.

$1413-8670$
Chronic carriers fall into at least three groups and may progress from one state to another. The first group is the immunotolerant phase, characterized by high levels of virus replication, viremia and antigenemia without any appreciable immunopathology. The second group is the immunoeliminative stage, which resembles that seen during the resolution of acute infections, consisting of active virus replication, immune reactivity and subsequent elevation in serum alanine aminotransferase (ALT) [2]. The chronic carrier may then serconvert with the loss of viral markers and the development of antibody to hepatitis B and antigen (HBeAg) latent phase [3]. In the third group, patients may experience a persistent, chronic infection, characterized by recurrent episodes of virus replication and active liver disease of varying duration. Expression of viral antigens on the surface of infected hepatocytes is believed to invoke a cytotoxic T-cell (CTL) response resulting in liver damage. The presence of the virus has been shown in several types of cells that are involved in the host immune response [4-7]. HBV DNA has been shown in T cells as well as B-cells and monocytes 
of chronic HBV carriers [8]. These infected cells present in the microenviroment could modify $\mathrm{T}$ cell and T-B cell interaction to bring about in vivo suppression of the $\mathrm{HBs} \mathrm{Ab}$ response [8].

One approach to studying the mechanism for HBV immunopathology is to analyse the phenotypic composition of peripheral blood or liver-derived leukocyte populations from chronically infected patients $[9,10]$. Previous analyses of peripheral blood momonuclear cells (PBMC) from patients with chronic hepatitis B had led to controversial results [10]. Some investigators demonstrated an impared balance of the $\mathrm{T}$-cell subsets related to decreases in the $\mathrm{CD}_{4} / \mathrm{CD}_{8}$ ratio $[11,12]$, whereas others showed an increase or no significant changes $[13,14]$. Recently, it has been shown that one of the reasons for such divergent results is the fact that chronic hepatitis B represents a dynamic series of disease states, particularly when viewed from a perspective of virus-host interactions [2]. They have shown changes in populations of circulating lymphocytes not only in patients but also in healthy carriers who seroconverted with loss of $\mathrm{HBeAg}$. These changes consist of a decrease in the percentages of $\mathrm{CD}_{4}^{+} \alpha \beta$ $\mathrm{TCR}^{+}$cells and an increase in both $\mathrm{CD}_{4}$ and $\mathrm{CD}_{8}$ cells bearing the $\gamma \delta \mathrm{TCR}[2]$.

In this study, we have analyzed the peripheral blood lymphocytes (PBL) of different patients with chronic hepatitis B in Iran and found differences not only in $\mathrm{CD}_{4}^{+} / \mathrm{CD}_{8}^{+}$populations, but also in the $\mathrm{B}$ cell population.

\section{Materials and Methods}

Subjects. PBL of 25 patients (15 males and 10 females between 22 years old to 80 years old and the mean of $44.5 \pm 17$ ) with chronic HBV infection and 72 healthy individuals without $\mathrm{HBV}$, hepatitis $\mathrm{C}$ virus (HCV) and HIV infection were used. All patients were admitted to different hospitals in Tehran, Iran, between 19971998. These patients were seropositive for HBsAg and seronegative for $\mathrm{HCV}$ and HIV, using Organon Teknika commercial kit. All patients had HBV infection for at least 6 months before selection, according to the hospital records, and were assigned into two groups based on $\mathrm{HBeAb}$ positive or negative (Table 1 ). These patients had normal range of ALT $(23.9 \pm 17.8)$.

Flow cytometry. Flow cytometry analysis was done on a Facscan with two colors of fluorescein isothiocyanate (FITC) and phycoerythrin (PE)-labeled antibodies against $\mathrm{CD}_{3}^{+} / \mathrm{CD}_{4}^{+}, \mathrm{CD}_{3}^{+} / \mathrm{CD}_{8}^{+}, \mathrm{CD}_{3}$ $\mathrm{CD}_{19}{ }^{+}, \mathrm{CD}_{3}^{+} / \mathrm{CD}_{19-}, \mathrm{CD}_{3-} / \mathrm{CD}_{56-16^{+}}$and $\mathrm{CD}_{3}^{+} / \mathrm{HLA}-$ $\mathrm{DR}+$ (Becton Dickinson). Cells $\left(1 \times 10^{4}\right)$ were analyzed using LYSIS II software (Becton Dickinson).

Statistical analysis. Data were compared with normal subjects using analysisi of variance (ANOVA).

\section{Results}

Screening patients based on chronic $H B V$. All patients $(n=25)$ used in this study were infected with HBV for at least 6 months and all were HBsAg positive (Table 1). Some patients in group I were positive for $\mathrm{HBeAg}(\mathrm{n}=4)$ and some $(n=4)$ were negative. No detectable $\mathrm{HBeAg}$ was seen in this group. We designated this group to the immunotolerant phase of HBV infection. In contrast, the Group II ( $\mathrm{n}=17)$, all patients were positive for $\mathrm{HBeAb}$ and all were negative for $\mathrm{HBeAg}$ (except 2 patients that were $\mathrm{HBe} A g$ positive).

Distribution of lymphocytes subset. To determine whether any particular immunophenotypic profiles could be associated with disease outcomes, the patients PBL composition were compared with control healthy individuals. As shown in Figure 1, a statistically significant reduction was seen in the percentage of $\mathrm{CD}_{3}^{+}$ cells $(\mathrm{p}<0.005)$ as well as $\mathrm{CD}_{8}^{+}$cells $(\mathrm{p}<0.01)$ in all patient as compared with 72 control subjects. In contrast, a significant increase in the percentage of $\mathrm{CD}_{19}{ }^{+}$cells $(\mathrm{p}<0.005)$ was seen in PBL of patients. The differences were seen in the percentages of other subset of T cells $\left(\mathrm{CD}_{4}{ }^{+}\right)$or NK cells $\left(\mathrm{CD}_{56}{ }^{+} / \mathrm{CD}_{16}{ }^{+}\right)$ and HLA-DR markers were not significant.

The phenotypic profiles were also compared between two groups (I and II) as well as within each 
group of patients. Figure 2 shows the distribution of lymphocyte subsets between two groups of chronic HBV patients. A significant increase in percentage of $\mathrm{CD}_{19}{ }^{+}$cells $(\mathrm{p}<0.001)$ was seen in group II having $\mathrm{HBeAb}+$ when compared with group I (HBeAb-). Also, in group II a significant decrease of $\mathrm{CD}_{3}^{+}$cells was observed.

Figure 3 shows that there in a correlation between increase of $\mathrm{CD}_{19}{ }^{+}$cells and decrease of $\mathrm{CD}_{3}{ }^{+}$cells in group II patients. No such correlation was seen between $\mathrm{CD}_{19}{ }^{+} \mathrm{B}$ cells and $\mathrm{CD}_{4}{ }^{+}$or $\mathrm{CD}_{8}{ }^{+}$cells (data not shown). No significant differences were seen between any of the two groups with respet to cells bearing the activation marker HLA-DR.

\section{Discussion}

In this report we analyzed the PBL of different patients with chronic hepatitis B infection with flow cytometry. Based on the presence and absence of $\mathrm{HBeAb}$, these patients were divided into two groups. In both groups, all the patients were $\mathrm{HBs} A g$ positive with a normal range of ALT. In group I, all patients were $\mathrm{HBe} A b$ negative, but half of them were $\mathrm{HBeAg}$ negative, which represent the late incubation or early chronic HBV infection. The other half was $\mathrm{HBeAg}$ positive which represents late chronic HBV infection. Such a profile represents an inability to mount an immune response because of large amounts of circulating virus. All patients in group II were positive for $\mathrm{HBeAb}$. In this group, two patients were also $\mathrm{HBeAg}$ positive representing early chronic infection or seroconversion. All other patients of group II were HBeAg negative representing the late seroconversion. This group had a functional immune response to HBV and was able to reduce the viral load following an initial flare up of liver disease, and supress further viral replication with the development of $\mathrm{HBeAb}$.

We have found that the immunophenotypic profiles of patients were different from healthy donors with a significant decrease in $\mathrm{CD}_{3}^{+} \mathrm{T}$ cells, specially $\mathrm{CD}_{8}^{+} \mathrm{T}$ cells and a significant increase in the $\mathrm{CD}_{19}{ }^{+} \mathrm{B}$ cells (Figure 1). When the phenotypic profiles of both groups were compared to with each other, such changes were more dominant in group II than group I (Figure 2). These changes may account for the presence or absence of $\mathrm{HBeAg}$ and the development of $\mathrm{HBeAb}$.

It has been shown that the HBV nucleocapsid or core antigen $(\mathrm{HBcAg})$ is extremely immunogenic during infection and after immunization. This antigen binds to specific membrane Ig antigen receptors on a high frequency of resting murine B cells sufficiently to induce B7.1 and B7.2 costimulatory molecules [15]. B cells can process and present $\mathrm{HBcAg}$ to naive Th cells more efficiently than macrophage or dendritic cells [15]. A unique feature of the $\mathrm{HBV}$ is the production of a secreted, nonparticulate form of the $\mathrm{HBcAg}$ designated hepatitis B precore $\mathrm{Ag}(\mathrm{HBe} \mathrm{Ag})$. The function of secretory $\mathrm{HBeAg}$ in the viral life cycle is unknown because it is not required either for infection or replication [16-18]. It has been proposed that the circulating HBeAg may have an immunoregulatory function in promoting viral persistance [19-21]. Recently, it has been shown that circulating $\mathrm{HBeAg}$ has the potential to preferentially deplete inflammatory HBeAg- and HBcAg- specific Th1 cells that are necessary for viral clearance, thereby, promoting hepatitis B virus persistence [22]. The mature HBeAgspecific Th1 cells preferentially depleted in the prephery after contact with secreted HBeAg by apoptosis [22]. HBeAg-specific Th2-like cells produce antiinflammatory cytokines such as IL-4 and IL-10, that would be expected to inhibit the expansion of $\mathrm{HBe} /$ HBcAg-specific CTL and Th1 effector cells necessary for the clearance of this noncytolytic virus [22]. Recent serologic evidence suggests that a Th1/Th2 subset imbalance in favor of $\mathrm{HBe} / \mathrm{HBcAg}$-specific Th2 cells may play a role in promoting chronic HBV infection [23].

There are controversial reports regarding $\mathrm{CD}_{4} / \mathrm{CD}_{8}$ ratio in patients with chronic $\mathrm{HBV}$ infection. Some investigators [24] showed either a decrease or increase and yet others showed no changes at all in $\mathrm{CD}_{4} / \mathrm{CD}_{8}$ ratio [10]. It has been shown that during yhe seroconversion phase, the percentage of $\mathrm{CD}_{3}$ lymphocytes, predominantly $\alpha \beta \mathrm{TCR}^{+} \mathrm{CD}_{4}$ cells $[24,25]$ decreases. However, if patients remained HBeAg-negative for 6 months after the hepatitis flare, a significant increase in $\gamma \delta \mathrm{TCR}$-bearing cells of both $\mathrm{CD}_{4}$ 
Table 1. Biochemical and virological characteristic of patients with chronic hepatitis B virus at the time of selection

\begin{tabular}{ccccccc}
\hline Groups & Patients & Sex & ALT & HBsAg & HBeAg & HBeAb \\
\hline I & 1 & F & 29 & + & - & - \\
I & 2 & M & 39 & + & - & - \\
I & 3 & F & 38 & + & - & - \\
I & 4 & M & 13 & + & - & - \\
I & 5 & M & 34 & + & + & - \\
I & 6 & M & 54 & + & + & - \\
I & 7 & M & 15 & + & + & - \\
I & 8 & F & 37 & + & + & - \\
II & 9 & F & 15 & + & + & + \\
II & 10 & M & 17 & + & + & + \\
II & 11 & F & 13 & + & - & + \\
II & 12 & M & 13 & + & - & + \\
II & 13 & M & 8 & + & - & + \\
II & 14 & M & 18 & + & - & + \\
II & 15 & M & 13 & + & - & + \\
II & 16 & F & 55 & + & - & + \\
II & 17 & F & 5 & + & - & + \\
II & 18 & M & 48 & + & - & + \\
II & 19 & M & 17 & + & - & + \\
II & 20 & F & 11 & + & - & + \\
II & 21 & M & 35 & + & - & + \\
II & 22 & M & 38 & + & - & + \\
II & 23 & F & 15 & + & - & + \\
II & 24 & M & 11 & + & - & + \\
II & 25 & F & 33 & + & + \\
\hline
\end{tabular}

Figure 1.

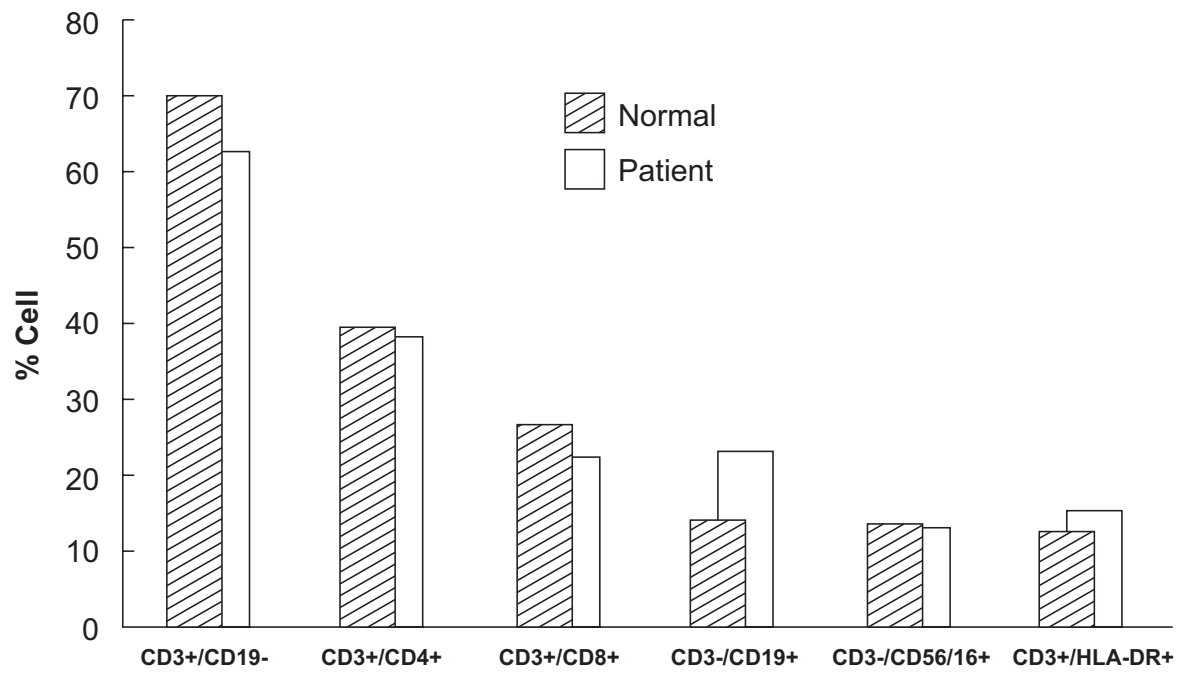

www.infecto.org.br/bjid.htm 
Figure 2.

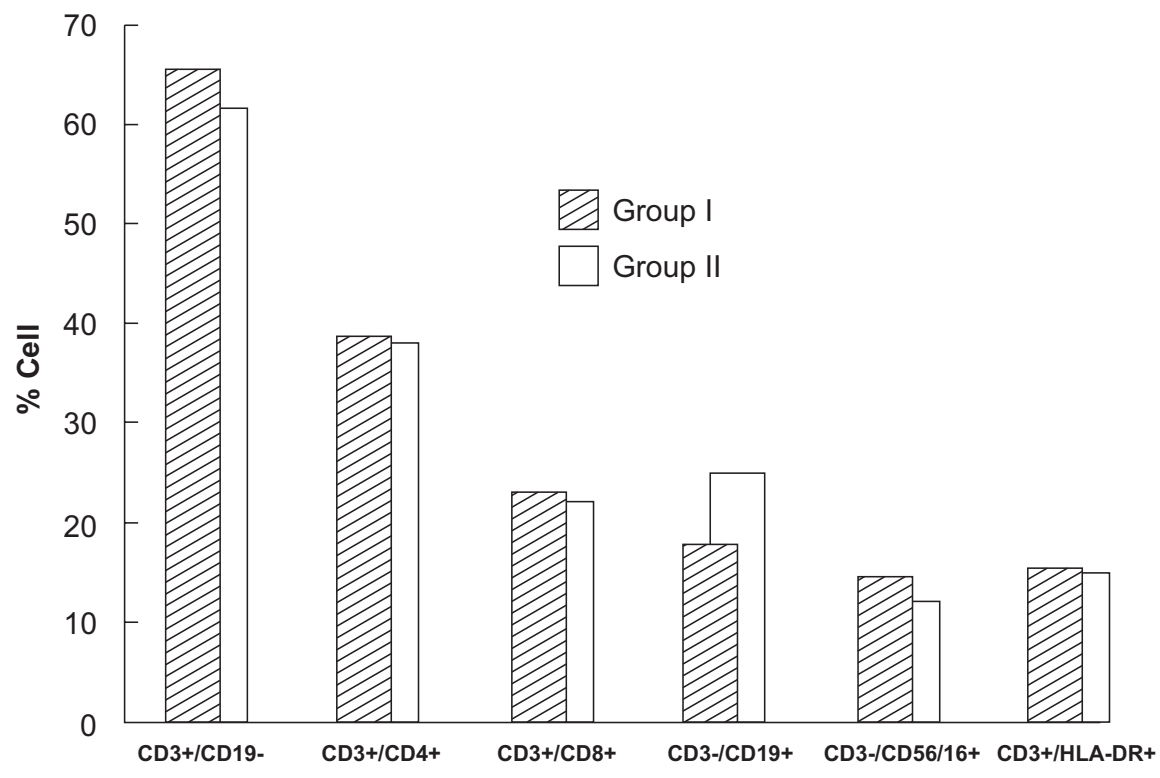

Figure 3.

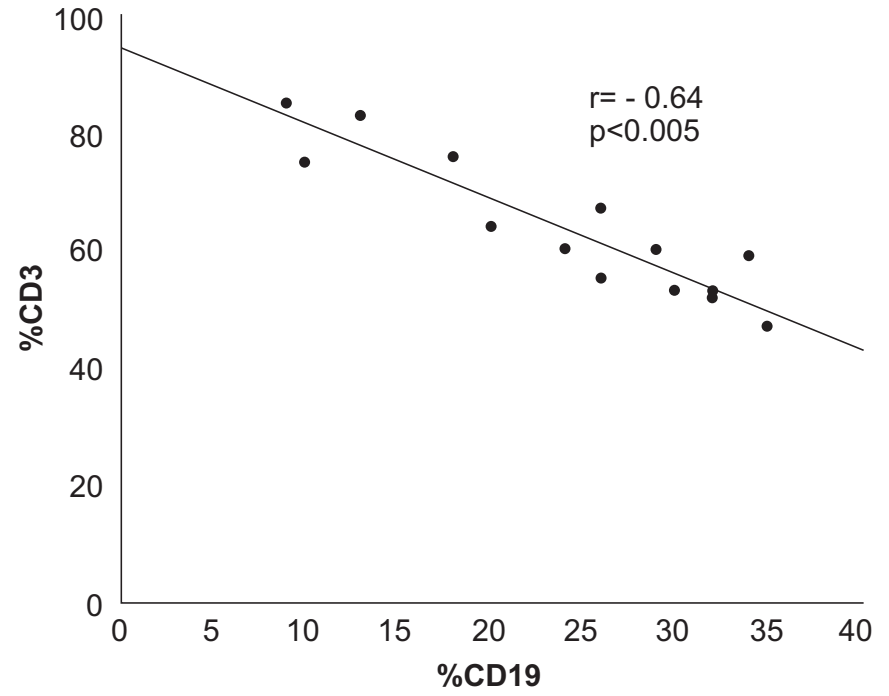

www.infecto.org.br/bjid.htm 
and $\mathrm{CD}_{8}$ subsets. T cells with $\gamma \delta$ receptor that account for $1 \%$ to $5 \%$ of PBL in normal human blood, have been shown to be cytotoxic against a number of targets $[26,27]$. We have shown that because of the significant decrease of $\mathrm{CD}_{8}^{+} \mathrm{T}$ cells this ratio increases (1.56 in normal vs. 1.69 in patients). We have seen a correlation between the increase of $\mathrm{CD}_{19}{ }^{+} \mathrm{B}$ cells, and the decrease of $\mathrm{CD}_{3}^{+} \mathrm{T}$ cells in group II patients with $\mathrm{HBe} A b$ positive. No such correlation was observed in group I with $\mathrm{HBeAb}$ negative or other cells. It seems, not only the ratio of $\mathrm{CD}_{4} / \mathrm{CD}_{8}$ in $\mathrm{HBV}$ infection is important but also the ratio of $\mathrm{CD}_{19} / \mathrm{CD}_{3}$ plays a role in chronic HBV infection.

\section{References}

1. Gerlich Wl.H., Lu X. Interaction of hepatitis B virus with hepatocytes. In: Mahy B.J. Compnas R.W. [eds]. Immunobiology and Pathogenesis of Perisistent Virus Infections. Amsterdam: OPA, 1996:195-208.

2. Sing G., Butterworth L., Chen X., et al. Composition of peripheral blood lymphocyte populations during different stages of chronic infection with hepatitis B virus. J Viral Hepatitis 1998;5:83-93.

3. Marinos G., Torre F., Choksi S., et al. Induction of T-helper cell response to hepatitis $\mathrm{B}$ core antigen in chronic hepatitis B: a major factor in activation of the host immune response to hepatitis B virus,. Hepatology 1995; $22: 1040-9$.

4. Romet-Lemonne J.L., Elfassi E., Haseltine W., Essex M. Infection of bone marrow cells by hepatitis B virus. Lancet 1983;ii:732-5.

5. Elfassi E., Romet-Lemonne J.L., Essex M., et al. Evidence of extrachromosomal forms of hepatitis B viral DNA in a bone marrow culture obtained from a patient recently infected with hepatitis B virus. Proc Natl Acad Sci USA 1984;81:3526-8.

6. Lie-Injo L.E., Balasegaram M., Lopez C.G., Herrera A.R. Hepatitis B virus DNA in liver and white blood cells of patients with hepatoma. DNA 1983;2:301-8.

7. Yoffe B., Noonan C.A., Melnick J.L., Hollinger F.B. Hepatitis B virus DNA in mononuclear cells and analysis of subsets for the presence of replicative intermediates of viral DNA. J Infect Dis 1986;98:471-7.

8. Nagaraju K., Naik S.R., Naik S. Functional implications of hepatitis B surface antigen ( $\mathrm{HBsAg}$ ) in the T cells of chronic HBV carriers. J Viral Hepatitis 1997;4:221-30.
9. Chu C.-M., Lliaw Y.-F. Peripheral T-cell subsets in asymptomatic hepatitis B-virus carriers. Cell Immunol 1986;98:533-7.

10. Dienstag J.L. Immunologic mechanisms in chronic viral hepatitis. In: Vyas G.N., Dienstag J.L., Hoofnagle J.H. [eds]. Viral Hepatitis and Liver Disease. New York: Grune\& Stratton, 1984: 135-66.

11. Thomas H.C., Brown D., Routhier G., et al. Inducer and suppressor T cells in hepatitis B virus induced liver disease. Hepatology 1982;2:202-4.

12. Alexander G.L.M., Mondelli M., Naumov N.V., et al. Functional characterization of peripheral blood lympfocytes in chronic HBsAg carriers. Clin Exp Immunol 1986;63:498-507.

13. Regenstein F.G., Roodman S.T., Perrillo R.P. Immunoregulatory $\mathrm{T}$ cells subsets in chronic hepatitis B virus infection: the innfluence of homosexuality. Hepatology 1983;3:951-4.

14. Robayes G., De Groote J., Vandeputte M. Suppressor cell function in liver disease. Lancet 1983;2:342.

15. Milich D.R., Chen M., Schödel F., et al. Role of cells in antigen presentation of the hepatitis B core. Proc Natl Acad Sci USA 1997;94:1468-53.

16. Chang C., Enders G., Sprengel R., et al. Expression of the precore region of an avian hepatitis $B$ virus is not required for viral replication. J Virol 1987;61:3322.

17. Schlicht H.J., Salfed J., Schaller H. The pre-C of the duck hepatitis B virus encodes a signal sequence which is essential for the synthesis and secretion of processed core patients but not for virus formation. J Virol 1987;61:3701.

18. Milich D.R., Chen M., Schodel F., et al. Role of B cells in antigen presentation of the hepatitis B core. proc Natl Acad Sci USA 1997;94:14648.

19. Milich D.R., Jones J., Hughes J., Maruyama T. Role of T cell tolerance in the persistence of hepatitis $B$ virus infection. J Immunother 1993; 14:226.

20. Milich D.R., Jones J., Hughes J., et al. Is a functional of the secreted hepatitis $\mathrm{Be}$ antigen to induce immunologic tolerance in utero? Proc Natl Acad Sci USA 1990;87:6599.

21. Thomas H.C., Meron J., Water J., Main J. Virus-host interaction in chronic hepatitis B virus infection. Semin Liver Dis 1988;8:342.

22. Milich D.R., Chen M.K., Hughes J.L., Jonnes J.E. The secreted hepatitis B precore antigen can modulate the immune response to the nucleocapsid: a mechanism for persistence. $J$ Immunol 1998;160:2013-21.

23. Maruyama T., McLachlan A., Lino S., et al. The serology of chronic hepatitis B infection revisited. J Clin Invest 1993;91:2586. 
24. Jung M.-C., Schraut W., Santantonio T., et al. Increased frequency of CD8 $+\mathrm{CD} 45 \mathrm{RO}+$ memory $\mathrm{T}$ lymphocytes in acute hepatitis B virus infection. J Hepatol 1993; 18:295-300.

25. Nikolopoulou V., Skoutelis A., Thomopoulos K., et al. An increased number of circulating $\gamma / \delta$ TCR + cells in patients with chronic viral hepatitis. FEMS Immunol Med Microbiol 1995; 10:115-8.

26. Sturm E., Braakman E., Fisch P., et al. Human V $\gamma 9 V \delta 2 T$ cell receptor- $\mathrm{V} \gamma \delta$ lymphocytes show specificity to Daudi Burkitt lymphoma cells. J Immunol 1990; $145: 3203-8$.

27. Bukowski J.F., Morita C.T., Brenner M.B. Recognition and destruction of virus-infected cells by human $\gamma \delta$ CTL. J Immunol 1994;153:5133-40. 